\title{
ANALISIS POLA MASA STUDI MAHASISWA FAKULTAS TEKNIK UNIVERSITAS DARMA PERSADA MENGGUNAKAN METODE CLUSTERING K-MEANS
}

\author{
Ayu Hardianti*1, Dewi Agushinta R. ${ }^{2}$ \\ ${ }^{1}$ Program Studi Magister Sistem Informasi, Program Pasca Sarjana, Universitas Gunadarma \\ ${ }^{2}$ Jurusan Sistem Informasi, Fakultas Ilmu Komputer dan Teknologi Informasi, Universitas Gunadarma \\ E-mail : ${ }^{1}$ hardianti.ayu1988@gmail.com, ${ }^{2}$ dewiar@staff.gunadarma.ac.id \\ *Penulis Korespondensi
}

(Naskah masuk: 18 Agustus 2018, diterima untuk diterbitkan: 28 Februari 2019)

\begin{abstract}
Abstrak
Lama studi mahasiswa menjadi salah satu faktor yang memengaruhi ketepatan waktu mahasiswa menyelesaikan kuliah. Berdasarkan kebijakan dari Badan Akreditasi Nasional Perguruan Tinggi (BAN PT) pada peraturan No 4 tahun 2017 mengenai Kebijakan Penyusunan Instrumen Akreditasi, lama studi merupakan salah satu tolak ukur dan elemen penilaian dalam akreditasi program studi. Dari data akademik Fakultas Teknik Universitas Darma Persada, banyak mahasiswa menempuh lama studi lebih dari empat tahun. Lama studi menjadi salah satu masalah pengelola program studi dalam hal kinerja akademik. Penelitian ini bertujuan menganalisis pola lama studi mahasiswa Fakultas Teknik Universitas Darma Persada dari data akademik. Teknik clustering algoritma K-Means digunakan dengan variabel-variabelnya adalah jurusan, daerah asal, umur, jenis kelamin, Indeks Prestasi Kumulatif (IPK), Satuan Kredit Semester (SKS), tahun masuk dan lama studi. Perangkat lunak Waikato Environment for Knowledge Analysis (WEKA) dipakai sebagai tool penganalisis. Tahap awal penelitian melalui pengumpulan data dari arsip atau database bagian Akademik yaitu data akademik mahasiswa Fakultas Teknik Universitas Darma Persada angkatan 2009 sampai 2014. Tahapan selanjutnya adalah preprocessing data yang dilakukan melalui analisis clustering algoritma K-Means dengan terlebih dahulu menghitung banyak cluster menggunakan metode Elbow dan interpretasi hasil. Dari hasil metode Elbow, jumlah cluster yang dipergunakan sebanyak 4 (empat) cluster. Berdasarkan hasil proses clustering K-Means, pembagian data pada masing-masing cluster adalah cluster 1 (satu) berjumlah 556 data (26\%), cluster 2 (dua) berjumlah 414 data (19\%), cluster 3 (tiga) berjumlah 189 data (9\%) dan cluster 4 (empat) berjumlah 1010 data (46\%). Selanjutnya, yang memiliki lama studi lebih dari 4 tahun terdapat pada cluster 2, cluster 3, cluster 4 dan mahasiswa yang memiliki masa studi 4 tahun ada pada cluster 1.
\end{abstract}

Kata kunci: algoritma K-Means, clustering, data mining, lama studi, WEKA

\section{PATTERN ANALYSIS OF THE STUDENT STUDY PERIOD IN THE FACULTY OF ENGINEERING AT DARMA PERSADA UNIVERSITY USING K-MEANS CLUSTERING METHOD}

\begin{abstract}
The duration of student study is one of the factors that influence the completing students' timeliness. Based on the policy of the National Accreditation Board of Higher Education (BAN-PT) in Regulation No. 4 of 2017 concerning the Policy for Preparing Accreditation Instruments, the duration of study is one of the benchmarks and evaluation elements in accreditation of study programs. From the Faculty of Engineering academic data, Darma Persada University, many students take more than four years of study. The duration of study is one of the problems of the study program manager in terms of academic performance. This study aims to analyze the old patterns of study by students of the Faculty of Engineering, Darma Persada University from academic data. K-Means algorithm clustering technique is used with the variables are majors, the area of origin, age, gender, Grade Point Average (GPA), Semester Credit Unit (SKS), year of entry and study duration. The Waikato Environment for Knowledge Analysis (WEKA) software is used as an analytic tool. The initial stage of research is through collecting data from archives or Academic sections, namely academic data from students of the Faculty of Engineering, Darma Persada University, 2009 to 2014. The next stage is preprocessing data through K-Means algorithm clustering analysis by first calculating many clusters using the Elbow method and result interpretation. From the Elbow method result, the number of clusters used is 4 (four) clusters. Based on the results of the K-Means clustering process, the data
\end{abstract}


sharing in each cluster is cluster 1 (one) totaling 556 data (26\%), cluster 2 (two) totaling 414 data (19\%), cluster 3 (three) totaling 189 data (9\%) and cluster 4 (four) totaling 1010 data (46\%). Furthermore, those who have more than 4 years of study are in cluster 2, cluster 3, cluster 4 and students who have a 4-year study period are in cluster 1 .

Keywords: clustering, data mining, K-Means algorithm, study period, WEKA.

\section{PENDAHULUAN}

Pendidikan adalah salah satu kunci kemajuan bangsa Indonesia, sampai dengan tahun 2015 terdapat 3.225 perguruan tinggi aktif di Indonesia dengan jumlah mahasiswa lebih dari lima juta orang yang tersebar di 34 provinsi (bps.go.id). Universitas Darma Persada adalah perguruan tinggi swasta di Indonesia, dengan jumlah mahasiswa sebanyak 9.865 orang pada tahun ajaran 2016/ 2017, yang tersebar dalam 15 program studi (forlap DIKTI, 2017).

Agar terwujud efisiensi perguruan tinggi maka pengelola perguruan tinggi dituntut untuk mengelola secara profesional. Salah satu faktor yang memengaruhi efisiensi adalah lama studi mahasiswa. Berdasarkan kebijakan dari Badan Akreditasi Nasional Perguruan Tinggi (BAN PT) yang terdapat pada peraturan No. 4 tahun 2017 mengenai Kebijakan Penyusunan Instrumen Akreditasi, lama studi merupakan salah satu tolak ukur dan elemen penilaian dalam akreditasi program studi (BAN PT, 2017). Berdasarkan data akademik dari program studi Fakultas Teknik Universitas Darma Persada yang terdiri dari tujuh program studi (Teknik Elektro, Teknik Industri, Teknik Informatika, Sistem Informasi, Teknik Mesin, Teknik Perkapalan dan Sistem Perkapalan), banyak mahasiswa yang lama studinya mencapai lebih dari empat tahun. Lama studi menjadi salah satu faktor masalah pengelola program studi sehingga dapat memengaruhi kinerja akademik.

Untuk mengatasi permasalahan mengenai lama studi, dibutuhkan sebuah sistem informasi yang dapat mengumpulkan data dalam jumlah besar. Salah satu teknik yang dapat digunakan adalah teknik data mining. Data Mining adalah teknik untuk menelusuri data kemudian membuat model yang digunakan untuk mencari pola data lain yang tidak berada dalam database yang disimpan (Prasetyo, 2012).

Analisis terhadap pola lama studi merupakan salah satu bagian dari teknik data mining. Metodemetode data mining, antara lain metode klasifikasi, asosiasi dan clustering. Penelitian yang menggunakan metode clustering untuk analisis pola lama studi mahasiswa masih sedikit dilakukan dibandingkan menggunakan metode lainnya. Cluster merupakan analisis yang mengelompokkan mahasiswa dengan perilaku atau ciri sama pada database mahasiswa yang mengandung informasi pada masa lalu (Hervianti, 2018). Salah satu algoritma untuk analisis cluster adalah K-Means clustering. K-Means clustering merupakan bagian pembelajaran tanpa pengawasan (unsupervised learning) (Prasetyo, 2012).

Penelitian sebelumnya yang dilakukan mengenai analisis pola lama studi mahasiswa dilakukan oleh Khyati Manvar dan Madhuri Rao yang berjudul "Predicting students' performance in higher education: A Data Mining Approach". Mereka menggunakan 500 data siswa pada tahun akademik 2009-2012 untuk menemukan pola memrediksi perilaku siswa. Teknik yang digunakan adalah algoritma clustering K-Means dan teknik Asosiasi Rule Mining algoritma Apriori. Hasil dari penelitian dengan menggunakan algoritma K-Means, terdapat 3 (tiga) kelompok (cluster) siswa yaitu poor, good, dan excellent. Sebanyak 32 siswa berada di cluster pertama (poor), 101 siswa di cluster kedua (good) dan 130 siswa di cluster ketiga (excellent). Hasil yang didapat dengan menggunakan algoritma Apriori untuk memrediksi kinerja mahasiswa berdasarkan nilai minimum support $20 \%$ dan minimum confidence $80 \%$ (Manvar dan Rao, 2014).

Penelitian yang dilakukan oleh Arief Jananto untuk memperkirakan waktu studi mahasiswa yang menggunakan teknik data mining klasifikasi algoritma Naïve Bayes, melakukan prediksi ketepatan waktu studi mahasiswa Teknik Informasi Universitas Stikubank. Variabel yang digunakan adalah kota lahir, jenis sekolah, jenis kelamin, kota sekolah dan data akademik selama kuliah sampai dengan semester 4. Hasil dari penelitian menunjukkan sebanyak 254 dari 258 mahasiswa diprediksi lulus tepat waktu dan sebanyak 4 mahasiswa diprediksi lulus tidak tepat waktu (Jananto, 2013).

Penelitian oleh Riska Haryati, Aji Sudarsono dan Eko Suryana yang berjudul "Implementasi Data Mining Untuk Memprediksi Masa Studi Mahasiswa Menggunakan Algoritma C4.5", berbasiskan pada pohon keputusan untuk menentukan mahasiswa lulus tepat waktu atau tidak. Tahap penelitian yang dilakukan, mengumpulkan data mahasiswa Fakultas Komputer Universitas Dehasen Bengkulu dengan variabel yang digunakan adalah jenis kelamin, IPK dan jumlah SKS menggunakan aplikasi Rapid Miner. Hasil dari proses C4.5 memberikan nilai accuracy 95\% dari hasil matriks confusion (Haryati, Sudarsono dan Suryana, 2015).

Penelitian oleh Ryan Dwi Pambudi, Ahmad Afif Supianto dan Nanang Yudi Setiawan yang berjudul "Prediksi Kelulusan Mahasiswa Berdasarkan Kinerja Akademik Menggunakan Pendekatan Data Mining Pada Program Studi Sistem Informasi Fakultas Ilmu Komputer Universitas Brawijaya", menggunakan 
teknik klasifikasi algoritma Naïve Bayes dengan melakukan prediksi ketepatan kelulusan mahasiswa prodi sistem informasi. Ada sebanyak 1.354 data mahasiswa angkatan 2011-2016 diuji. Hasil pengujian usability dengan System Usability Scale (SUS) menunjukkan bahwa 57.5 termasuk adjective rating Good (Pambudi, Supianto dan Setiawan, 2019).

Berdasarkan penelitian-penelitian yang pernah dilakukan mengenai lama studi mahasiswa, analisisis pola lama studi mahasiswa yang akan dilakukan Penulis menggunakan teknik clustering algoritma KMeans. Penelitian ini diharapkan dapat membantu pengelola program studi Fakultas Teknik Universitas Darma Persada melakukan analisis data kelulusan mahasiswa untuk meningkatkan kinerja akademik.

\section{METODE PENELITIAN}

\subsection{Tahapan Penelitian}

Tahapan penelitian yang dilakukan dapat dilihat pada Gambar 1.

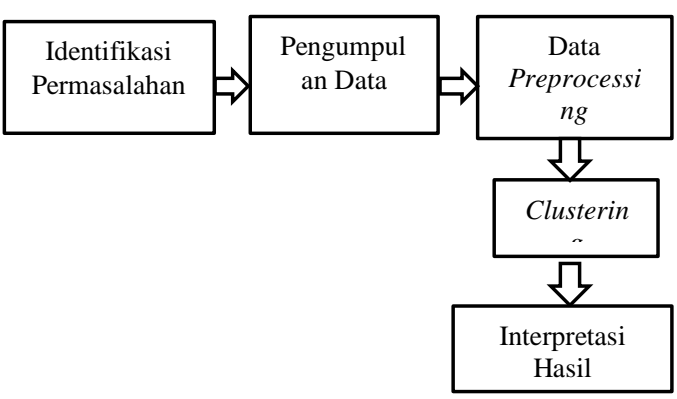

Gambar 1. Tahapan Penelitian

Pada gambar 1 ada 5 (lima) tahapan penelitian yang dilakukan, dimulai dari identifikasi permasalahan, mengumpulkan data, data preprocessing, clustering serta interpretasi hasil.

\subsection{Identifikasi Masalah}

Pada tahap identifikasi masalah, informasi yang dibutuhkan adalah lama studi mahasiswa. Pengumpulan informasi yang dilakukan dengan observasi pustaka dan studi literatur dari berbagai jurnal dan penelitian yang terkait lama studi mahasiswa.

\subsection{Pengumpulan Data}

Pada tahap pengumpulan data, data yang dibutuhkan dikumpulkan Penulis sehingga dapat diolah menjadi informasi yang diharapkan. Tahap mengumpulkan data dilakukan dengan mendokumentasikan data akademik mahasiswa Fakultas Teknik Universitas Darma Persada angkatan 2009 hingga 2014. Adapun deskripsi data ditunjukkan pada Tabel 1, sedangkan penjelasan tiap atributnya pada Tabel 2 .

\begin{tabular}{cc} 
& Tabel 1. Deskripsi Data \\
\hline Jenis Data & \multicolumn{1}{c}{ Item Data } \\
\hline Data akademik & $\begin{array}{l}\text { Daerah asal, umur, jenis kelamin } \\
\text { Jurusan, IPK, SKS, tahun masuk } \\
\text { dan lama studi }\end{array}$ \\
\hline
\end{tabular}

Tabel 1 merupakan tabel data akademik yang terdiri dari 8 (delapan) atribut yaitu jurusan, daerah asal, umur, jenis kelamin, IPK (Indeks Prestasi Kumulatif), SKS (Satuan Kredit Semester), tahun masuk dan lama studi.

\begin{tabular}{|c|c|c|}
\hline Atribut & Jenis Data & Keterangan \\
\hline Daerah asal & Nominal & $\begin{array}{l}\text { Daerah tempat tinggal } \\
\text { sebelum kuliah }\end{array}$ \\
\hline Umur & Numerik & $\begin{array}{l}\text { Usia mahasiswa saat } \\
\text { masuk universitas }\end{array}$ \\
\hline Jenis kelamin & Nominal & Jenis kelamin mahasiswa \\
\hline Jurusan & Nominal & $\begin{array}{l}\text { Program studi yang } \\
\text { diambil mahasiswa }\end{array}$ \\
\hline IPK & Numerik & $\begin{array}{c}\text { Indeks Prestasi Kumulatif } \\
\text { (IPK) merupakan tolak } \\
\text { ukur kemampuan } \\
\text { mahasiswa }\end{array}$ \\
\hline SKS & Numerik & $\begin{array}{l}\text { Total SKS yang telah } \\
\text { ditempuh mahasiswa }\end{array}$ \\
\hline Tahun Masuk & Numerik & Tahun masuk mahasiswa \\
\hline Lama Studi & Nominal & $\begin{array}{c}\text { Waktu studi yang } \\
\text { ditempuh mahasiswa } \\
\text { selama masa perkulihaan } \\
\text { sampai lulus }\end{array}$ \\
\hline
\end{tabular}

\subsection{Data Preprocessing}

Pada tahap ini, dilakukan data preprocessing untuk mempersiapkan data. Pada penelitian ini, data preprocessing dilakukan melalui langkah pembersihan data (cleansing) dan inisialisasi atau pemberian label data. Pada tahap inisialisasi atau pemberian label, data daerah asal, jenis kelamin, jurusan dan lama studi yang bernilai nominal, terlebih dahulu dikonversikan ke dalam bentuk numerik.

a. Inisialisasi nilai atribut daerah asal

Pada atribut daerah asal dari data mahasiswa dilakukan inisialisasi nilai atribut menjadi kode numerik seperti ditunjukkan pada Tabel 3.

Tabel 3. Inisialisasi Daerah Asal

\begin{tabular}{cc}
\hline Provinsi & Inisialisasi \\
\hline Aceh & 101 \\
Sumatera Utara & 102 \\
Sumatera Barat & 103 \\
Riau & 104 \\
Jambi & 105 \\
Sumatera Selatan & 106 \\
Bengkulu & 107 \\
Lampung & 108 \\
DKI Jakarta & 109 \\
Jawa Barat & 110 \\
Jawa Tengah & 111 \\
Banten & 112 \\
Jawa Timur & 113 \\
Yogyakarta & 114 \\
Bali & 115 \\
\hline
\end{tabular}




\begin{tabular}{cc}
\hline Provinsi & Inisialisasi \\
\hline NTB & 116 \\
NTT & 117 \\
Kalimantan Barat & 118 \\
Kalimantan Tengah & 119 \\
Kalimantan Selatan & 120 \\
Kalimantan Timur & 121 \\
Kalimantan Utara & 122 \\
Sulawesi Utara & 123 \\
Sulawesi Tengah & 124 \\
Sulawesi Selatan & 125 \\
Sulawesi Tenggara & 126 \\
Gorontalo & 127 \\
Sulawesi Barat & 128 \\
Maluku & 129 \\
Maluku Utara & 130 \\
Papua & 131 \\
Papua Barat & 132 \\
\hline
\end{tabular}

b. Inisialisasi atribut jenis kelamin Pada atribut jenis kelamin dari data mahasiswa dilakukan inisialisasi nilai atribut menjadi kode numerik seperti ditunjukkan pada Tabel 4.

Tabel 4. Inisialisasi Jenis Kelamin

\begin{tabular}{cc}
\hline Jenis Kelamin & Inisialisasi \\
\hline Laki-laki & 11 \\
Perempuan & 12 \\
\hline
\end{tabular}

c. Inisialisasi atribut jurusan

Pada atribut jurusan dari data mahasiswa dilakukan inisialisasi nilai atribut menjadi kode numerik seperti ditunjukkan pada Tabel 5.

\begin{tabular}{cc}
\multicolumn{2}{c}{ Tabel 5. Inisialisasi Jurusan } \\
\hline Jurusan & Inisialisasi \\
\hline Teknik Elektro & 1 \\
Teknik Industri & 2 \\
Teknik Informatika & 3 \\
Sistem Informasi & 4 \\
Teknik Mesin & 5 \\
Teknik Perkapalan & 6 \\
Sistem Perkapalan & 7 \\
\hline
\end{tabular}

d. Inisialisasi atribut lama studi

Pada atribut lama studi dari data mahasiswa dilakukan inisialisasi nilai atribut menjadi kode numerik seperti ditunjukkan pada Tabel 6.

\begin{tabular}{cc} 
Tabel 6. Inisialisasi Data Lama Studi \\
\hline Lama Studi & Inisialisasi \\
\hline$=4$ tahun & 21 \\
$>4$ tahun & 22 \\
\hline
\end{tabular}

\subsection{Clustering}

Berdasarkan pembahasan yang telah disebutkan di awal, penelitian dengan metode clustering ini menggunakan metode Elbow untuk menentukan jumlah cluster (k) dan algoritma K-Means.

\subsubsection{Metode Elbow}

Metode Elbow adalah metode untuk menetapkan jumlah cluster terbaik di dalam proses clustering dengan cara melihat perbandingan hasil setiap cluster yang membentuk siku (Elbow) (Merliana, Ernawati dan Santoso, 2015). langkah-langkah metode Elbow untuk menentukan nilai $\mathrm{k}$ pada algoritma K-Means adalah (Bholowalia dan Kumar, 2014):

1. Mulai

2. Pemberian label nilai awal $\mathrm{k}$

3. Tambah nilai $\mathrm{k}$

4. Lihat nilai Sum of Square Error dari tiap nilai $\mathrm{k}$, dalam percobaan ini nilai Sum of Error didapat dari nilai Sum of Square Error yang ada pada tools WEKA

5. Lihat hasil selisih Sum of Square Error dengan nilai k yang yang paling besar penurunanya

6. Nilai $\mathrm{k}$ yang selisih penurunannya paling besar ditetapkan sebagai nilai k yang berbentuk siku dan ditetapkan sebagai jumlah cluster

7. Selesai.

Rumus Sum of Square Error (SSE) pada KMeans (Kordinariya dan Makwana, 2013):

$$
W(S, C)=\sum_{k=1}^{k} \sum_{i \in S_{k}}\left\|y_{i}-C_{k}\right\|^{2}
$$

Dengan:

$$
\begin{array}{ll}
\mathrm{S} & : \mathrm{K}-\text { cluster yang telah terbentuk } \\
\mathrm{y}_{\mathrm{i}} & \text { : Data pada y pada indeks ke-i } \\
\mathrm{C}_{\mathrm{k}} & \text { : Rerata K-cluster pada nilai } \mathrm{k}(1,2, \ldots, \mathrm{k}) .
\end{array}
$$

\subsubsection{Algoritma K-Means}

K-Means adalah algoritma yang mampu mengelola data dalam jumlah banyak, namun sangat mudah dalam proses clustering (Rahadian, Kurnianingtyas, Mahardika, Maghfira dan Cholissodin, 2017).

Berikut merupakan tahap-tahap pada algoritma K-Means pada Gambar 2.

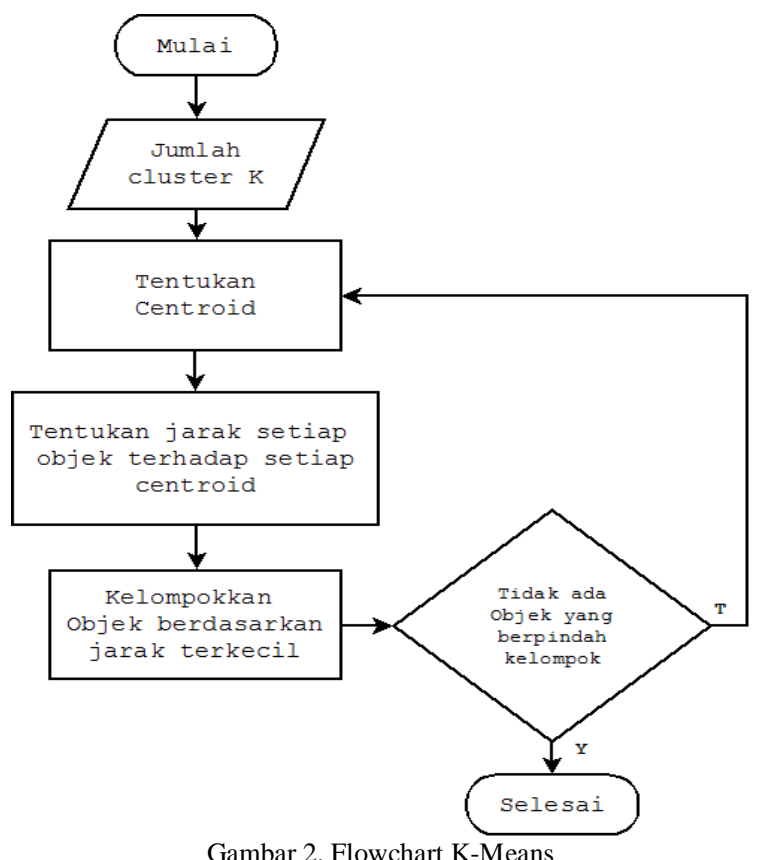

Gambar 2. Flowchart K-Means 
Penentuan centroid awal dilakukan secara random atau acak pada k cluster. Persamaan (2) untuk mencari nilai centroid (titik pusat) ke-i selanjutnya, penentuan centroid awal.

Dengan

$$
v=\frac{\sum_{i=1}^{n} X_{i}}{n} ; n=1,2,3, \ldots, n
$$

$\mathrm{V}:$ Centroid pada cluster

$\mathrm{x}_{\mathrm{i}}$ : Objek ke- $i$

n : Jumlah objek

Setelah menghitung centroid per cluster selanjutnya menghitung jarak antara objek dengan centroid dengan persamaan (3) Euclidian Distance.

$$
(x, y)=|x-y|=\sqrt{\sum_{i}^{n}=1\left(x_{i}-y_{i}\right)^{2}} ; i=1,2,3, \ldots, \mathrm{n}
$$

Dengan

$\mathrm{x}_{\mathrm{i}}$ : objek x ke-i

$\mathrm{y}_{\mathrm{i}}$ : sumber y ke-i

$\mathrm{n}$ : jumlah objek

Pada penelitian ini delapan atribut, yaitu daerah asal, umur, jenis kelamin, jurusan, IPK, SKS, tahun masuk dan lama studi dimasukkan sebagai variabel $\mathrm{x}$ dan $\mathrm{y}$ ke persamaan (3).

\subsection{Interpretasi Hasil}

Hasil luaran (output) dari data mining yang menerapkan metode analisis cluster atau clustering algoritma K-Means berupa deskripsi mahasiswa berdasarkan ke delapan atribut tersebut.

\section{HASIL DAN PEMBAHASAN}

Data yang digunakan penelitian ini adalah data akademik mahasiswa Universitas Darma Persada Fakultas Teknik angkatan 2009 sampai tahun 2014 sebanyak 2.182. Tahapan awal penelitian ini adalah tahapan preprocessing data yaitu cleansing data dan inisialisasi/ label data.

\subsection{Menentukan Banyak Cluster Metode Elbow}

Setelah melakukan tahap preprocessing data, tahapan selanjutnya adalah menentukan banyak cluster dengan metode Elbow. Percobaan dilakukan tiga (3) kali, yaitu 2.182 data $(100 \%$ dari data akademik), 1.746 data ( $80 \%$ dari data akademik) dan 1.310 data (60\% dari data akademik). Banyak cluster yang akan diuji adalah dari $\mathrm{k}=2$ hingga $\mathrm{k}=8$ (Merliana, Ernawati dan Santoso, 2015).

\subsubsection{Percobaan I : 2.182 Data Akademik}

Nilai Sum of Square Error (SSE) yang ada di dalam aplikasi WEKA 3.8.2 terhadap 2.182 data akademik mahasiswa memberikan hasil yang mengalami penurunan selisih paling besar pada nilai cluster $(\mathrm{k})=4$, selisih nilai Sum of Square Error (SSE) dapat dilihat pada tabel 7 dan gambar 3.
Tabel 7. Hasil Sum of Square Error 2.182 Data

\begin{tabular}{ccc}
\hline Cluster & $\begin{array}{c}\text { Hasil Sum of } \\
\text { Square Error } \\
\text { (SSE) }\end{array}$ & Selisih \\
\hline 2 & 605.8204 & 605.8204 \\
3 & 514.0231 & 91.79736 \\
4 & 354.7425 & 159.28061 \\
5 & 303.3396 & 51.40284 \\
6 & 282.9092 & 20.430426 \\
7 & 198.0862 & 84.822974 \\
8 & 256.8127 & -58.7265 \\
\hline
\end{tabular}

\section{Metode Elbow}

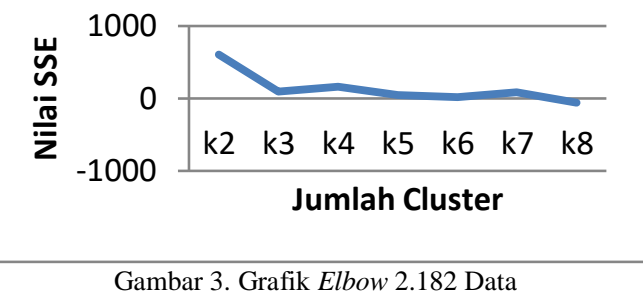

\subsubsection{Percobaan II : 1.746 Data Akademik}

Nilai Sum of Square Error (SSE) yang ada di dalam aplikasi WEKA 3.8.2 terhadap 1.746 data akademik mahasiswa yang penurunan selisih paling besar adalah pada cluster $(\mathrm{k})=4$, selisih nilai Sum of Square Error (SSE) dapat dilihat pada tabel 8 dan gambar 4.

\begin{tabular}{ccc}
\multicolumn{3}{c}{ Tabel 8. Hasil Sum of Square } \\
Cluster & $\begin{array}{c}\text { Hasil Sum of } \\
\text { Square Error } \\
\text { (SSE) }\end{array}$ & Selisih \\
\hline 2 & 648.6235 & 648.6235 \\
3 & 591.0298 & 57.5937 \\
4 & 443.0051 & 148.0247 \\
5 & 346.9833 & 96.0218 \\
6 & 322.2287 & 24.7546 \\
7 & 294.6317 & 27.597 \\
8 & 267.5738 & 27.0579 \\
\hline
\end{tabular}

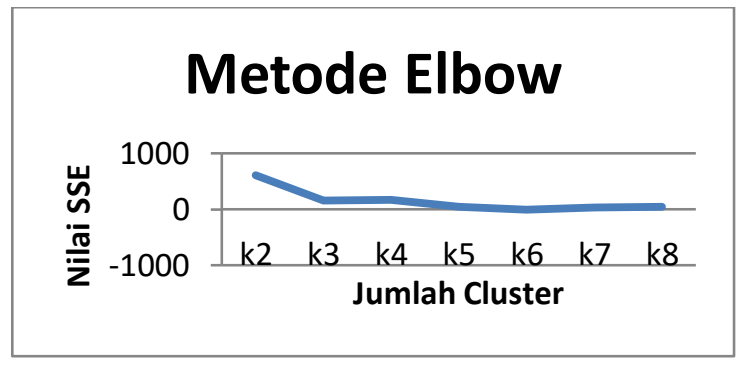

Gambar 4. Grafik Elbow 1.746 Data

\subsubsection{Percobaan III : 1.310 Data Akademik}

Nilai Sum of Square Error (SSE) yang ada di dalam aplikasi WEKA 3.8.2 terhadap 1.310 data akademik mahasiswa yang mengalami penurunan selisih paling besar adalah juga pada cluster $(\mathrm{k})=4$, selisih nilai Sum of Square Error (SSE) dapat dilihat pada Tabel 9 dan Gambar 5. 


\begin{tabular}{ccc}
\multicolumn{3}{c}{ Tabel 9. Hasil Sum of Square } \\
Cluster & $\begin{array}{c}\text { Hasil Sum of } \\
\text { Square Error } \\
\text { (SSE) }\end{array}$ & Selisih \\
\hline 2 & 607.9075 & 607.9075 \\
3 & 448.8437 & 159.0638 \\
4 & 278.4295 & 170.4142 \\
5 & 229.1670 & 49.2625 \\
6 & 236.8686 & -7.7016 \\
7 & 210.4037 & 26.4649 \\
8 & 163.4165 & 46.9872 \\
\hline
\end{tabular}

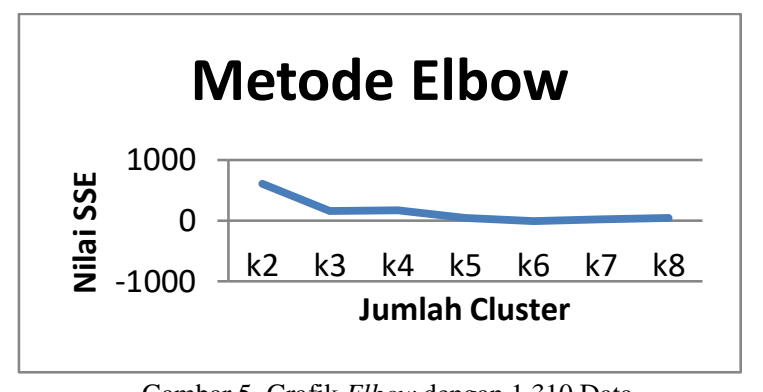

Gambar 5. Grafik Elbow dengan 1.310 Data

Dari ketiga percobaan berdasarkan data akademik mahasiswa Fakultas Teknik, terjadi penurunan selisih nilai Sum of Square Error (SSE) yang paling besar semua pada cluster $(\mathrm{k})=4$, sehingga jumlah cluster yang digunakan dalam penelitian ini adalah nilai cluster $(\mathrm{k})=4$. Nilai $\mathrm{k}=4$ akan digunakan sebagai jumlah cluster untuk tahapan selanjutnya.

\subsection{Analisis Hasil Clustering}

Analisis ini menggunakan data akademik mahasiswa Fakultas Teknik angkatan tahun 2009 sampai tahun 2014 yang telah lulus dan telah melalui tahap preprocessing sebanyak 2.182 data. Perhitungan pada algoritma K-Means dengan bantuan tool WEKA 3.8.2 diawali dengan menentukan jumlah cluster. Penelitian ini menggunakan 4 cluster berdasarkan hasil uji coba dengan metode Elbow sebelumnya. Data yang digunakan pada penelitian ini harus dikonversi dahulu menjadi file yang dapat diproses oleh WEKA 3.8.2 yaitu file .csv dengan nama file data_akademik_mahasiswa.csv.

Berdasarkan data hasil clustering dengan total 2.182 data dengan 8 (delapan) atribut (jurusan, provinsi, umur, jenis kelamin, IPK, SKS, tahun masuk dan lama studi) didapatkan hasil clustering sampai iterasi ke-11, dengan titik pusat tidak berubah. Nilai Sum of Square Erros (SSE) adalah 517.8904605474909. Titik pusat awal pada setiap cluster dapat dilihat pada tabel 10.

Tabel 10. Titik Pusat Awal Tiap Cluster

\begin{tabular}{ccccccccc}
\hline $\begin{array}{c}\text { Titik } \\
\text { Pusat } \\
\text { Awal }\end{array}$ & Jur & Prop & U & JK & IPK & $\begin{array}{c}\text { SK } \\
\text { S }\end{array}$ & Msk & $\begin{array}{c}\text { Lama } \\
\text { Studi }\end{array}$ \\
\hline $\begin{array}{c}\text { Cluster } \\
1\end{array}$ & 5 & 109 & 18 & 11 & 2.64 & 134 & 2013 & 22 \\
$\begin{array}{c}\text { Cluster } \\
2\end{array}$ & 1 & 109 & 18 & 11 & 1.03 & 62 & 2014 & 22 \\
$\begin{array}{c}\text { Cluster } \\
3\end{array}$ & 3 & 110 & 45 & 11 & 2.92 & 143 & 2014 & 22 \\
$\begin{array}{c}\text { Cluster } \\
4\end{array}$ & 3 & 110 & 18 & 11 & 1.95 & 65 & 2014 & 22 \\
\hline
\end{tabular}

data (19\%), cluster 3 berjumlah 189 data (9\%) dan cluster 4 berjumlah 1010 data (46\%). Pembagian data pada masing-masing cluster dilihat pada tabel 11 .

\begin{tabular}{ccc} 
& Tabel 11. Jumlah Data Cluster \\
\hline Cluster & $\begin{array}{c}\text { Banyak } \\
\text { Data }\end{array}$ & $\begin{array}{c}\text { Data dalam Cluster } \\
(\%)\end{array}$ \\
\hline Cluster 1 & 569 & 26 \\
Cluster 2 & 414 & 19 \\
Cluster 3 & 189 & 9 \\
Cluster 4 & 1010 & 46 \\
\hline
\end{tabular}

Dari hasil clustering K-Means yang telah diperoleh dari tool WEKA, beberapa gambaran terhadap pola lama studi mahasiswa antara lain:

1. Data yang memiliki lama studi lebih dari 4 tahun ada pada cluster 2 , cluster 3 , cluster 4 ; mahasiswa yang memiliki masa studi 4 tahun di cluster 1 .

2. Pengelompokkan berdasarkan SKS dan IPK memiliki kemiripan dengan pengelompokkan berdasarkan lama studi, cluster 1 memiliki IPK 3.1936 dengan SKS 146.1371, sedangkan pada cluster 2, cluster 3 dan cluster 4 memiliki IPK kurang dari 3 dan SKS kurang dari 146 yaitu masingmasing IPK 2.0114 dan SKS 112.756, IPK 2.4043 dan SKS 114.2381, IPK 2.1563 dan SKS 97.096. Mahasiswa yang lulus tepat waktu (4 tahun) adalah yang memiliki IPK lebih besar atau sama dengan 3 dengan jumlah SKS yang ditempuh 146 SKS.

3. Berdasarkan tahun masuk, mahasiswa tahun 2012 pada cluster 1 (lulus 4 tahun) diperkirakan lulus tahun 2016, mahasiswa 2009 pada cluster 2 (lulus lebih dari 4 tahun) ini diperkirakan lulus setelah tahun 2012, mahasiswa 2009 pada cluster 3 (lulus lebih dari 4 tahun) diperkirakan lulus setelah tahun 2016, mahasiswa tahun 2013 pada cluster 4 (lulus lebih dari 4 tahun) diperkirakan lulus setelah tahun 2018.

4. Berdasarkan atribut jenis kelamin, jenis kelamin laki-laki memiliki peluang sama besar antara lulus tepat waktu dan tidak tepat waktu, sedangkan untuk jenis kelamin perempuan, peluang lulusnya menjadi tidak tepat waktu.

\section{KESIMPULAN DAN SARAN}

Penelitian ini memberikan gambaran mengenai analisis pola lama studi mahasiswa di Fakultas Teknik Universitas Darma Persada menggunakan teknik clustering algoritma K-Means. Kelompok mahasiswa yang memiliki lama studi tepat 4 tahun berada pada cluster 1 dan kelompok mahasiswa dengan lama studi lebih dari 4 tahun berada pada cluster 2, cluster 3 dan cluster 4 . Hasil analisis proses 
K-Means pada tools WEKA, ada 2 (dua) dari 8 (delapan) atribut atau variabel yang digunakan pada penelitian ini mempengaruhi lama studi mahasiswa tepat 4 tahun yaitu jumlah SKS dan IPK.

Tabel 12 merupakan tabel hasil clustering dengan algoritma K-Means.

Tabel 12. Hasil Clustering K-Means

\begin{tabular}{ccccc}
\hline Atribut & Cluster & Cluster & Cluster & Cluster \\
& $\mathbf{1}$ & $\mathbf{2}$ & $\mathbf{3}$ & $\mathbf{4}$ \\
\hline Jurusan & 3.5554 & 3.5459 & 3.418 & 3.6644 \\
Provinsi & 109. & 109.673 & 109.851 & 109.858 \\
& 7715 & 9 & 9 & 4 \\
Umur & 20.4763 & 20.8285 & 20.4127 & 20.1941 \\
Jenis & 11.1986 & 11 & 12 & 11 \\
Kelamin & & & & \\
IPK & 3.1936 & 2.0114 & 2.4043 & 2.1563 \\
SKS & 146.137 & 112.756 & 114.238 & 97.096 \\
& 1 & & 1 & \\
Tahun & 2012.64 & 2009.87 & 2012.28 & 2013.25 \\
Masuk & 32 & 92 & 04 & 45 \\
Lama Studi & 21 & 22 & 22 & 22 \\
& & & & \\
Jumlah & 569.0 & 414.0 & 189.0 & 1010.0 \\
data & & & & \\
\hline
\end{tabular}

SKS lebih dari atau sama dengan 146 dan IPK lebih dari atau sama dengan 3 menyebabkan lama studi tepat waktu, begitu sebaliknya. Pada penelitian selanjutnya, teknik data mining clustering lainnya atau penggabungan dua teknik data mining dan penambahan metode untuk mengukur kualitas dan kekuatan cluster dapat dipertimbangkan.

\section{DAFTAR PUSTAKA}

B. A. N. Indonesia, "Peraturan Badan Akreditasi Nasional PT No 4/2017," 2017.

BHOLOWALI, P., dan KUMAR, A., 2014. A Clustering Techinique Based on Elbow Method and K-Means in WSN. International Journal of Computer Applications. Vol. 105, No. 9. pp. 17-24.

BPS. 2015. Jumlah perguruan tinggi mahasiswa dan tenaga edukatif negeri dan swasta di bawah kementrian pendidikan dan kebudayaan, [Online] Tersedia di: <https://www.bps.go.id/> [Diakses 2 Januari 2018]

FORLAP DIKTI. 2008. Pangkalan Data Pendidikan Tinggi Kementrian Riset, Teknologi dan Pendidikan Tinggi, [Online] Tersedia di: <https://forlap.ristekdikti.go.id/> [Diakses 2 Januari 2018]

HARYATI, S., SUDARSONO, A., \& SURYANA, E., 2015. Implementasi Data Mining Untuk Memprediksi Masa Studi Mahasiswa
Menggunakan C4.5 (Studi Kasus: Universitas Dehasen Bengkulu). Jurnal Media Infotama. Vol. 11, No 2. pp. 130-138.

HERVIANTI, S.P., 2018. Analisis Pengelompokkan Penyebaran Lulusan Mahasiswa Universitas Gunadarma Menggunakan Metode Clustering. IKRAITH-Informatika. Vol. 2, No 2. pp. 42-48.

JANANTO, A., 2013. Algoritma Naïve Bayes Untuk Mencari Perkiraan Waktu Studi Mahasiswa. Jurnal Teknologi Informasi Dinamik. Vol. 18, No 1. pp. 9-16.

KODINARIYA, T., dan MAKWANA, P., 2013. Review on determining number of Cluster in K-Means Clustering. International Journal of Advance Research in Computer Science and Management Studies. Vol. 1, Issue 6. pp. 90-95.

MANVAR, K., dan RAO, M., 2014. Predicting student's performance in higher education: A Data Mining Approach. International Journal of Scientific \& Engineering Research. Vol. 5, Issue 2. pp. 1024-1027.

MERLIANA, E., ERNAWATI, \& SANTOSO, J., 2015. Analisis Penentuan Jumlah Cluster Terbaik Pada Metode K-Means Clustering. Prosisding Seminar Nasional Multi Ilmu \& Call For Papers Unisbank, pp. 17-24.

PAMBUDI, R., SUPIANTO, A., \& SETIAWAN, N., 2019. Prediksi Kelulusan Mahasiswa Berdasarkan Kinerja Akademik Menggunakan Pendekatan Data Mining Pada Program Studi Sistem Informasi Fakultas Ilmu Komputer Universitas Brawijaya. Jurnal Pengembangan Teknologi dan Ilmu Komputer. Vol. 3, No. 3. pp. 21942200 .

PRASETYO, E., 2012. Data Mining Mengolah Data Menjadi Informasi Menggunakan Matlab, Yogyakarta: Andi.

RAHADIAN, B., KURNIANINGTYAS, D., MAHARDIKA, D., MAGHFIRA, T., dan CHOLISSODIN, I., 2017. Analisis Judul Majalah Kawanku Menggunakan Clustering K-Means Dengan Konsep Simulasi Big Data Pada Hadoop Multi Mote Cluster. Jurnal Teknologi Informasi dan Ilmu Komputer (JTIIK). Vol. 4, No. 2. pp. 75-80. 
Halaman ini sengaja dikosongkan 